\title{
FAMILY ALLOTMENT GARDENS - THE CASE OF THE POZNAŃ AGGLOMERATION
}

\author{
Magdalena Szczepańska \\ Institute of Socio-Economic Geography and Spatial Management \\ Adam Mickiewicz University \\ Bogumiła Krygowskiego 10, 61-810 Poznań: Poland \\ szmagda@amu.edu.pl
}

\begin{abstract}
In many European countries horticultural production in cities occupies a special position in their spatial policies and is financially supported by their authorities. Today, it is emphasised that urban land in agricultural use performs not only productive and economic functions, but also many more functions of great importance to a city, including ecological, health- and landscape-related, recreational, and social ones.

In Poland, after the period of economic and political transformation, one can observe a dynamic expansion of urban areas and their strong pressure on farmland most valuable in productive and landscape terms. In conceptions and documents on spatial development of urbanised areas, agricultural functions tend to be marginalised or perceived as specific to rural areas.

A special form of urban horticulture is gardening, including allotment gardens, which have a rich tradition and a history more than a hundred years long. The reasons for the appearance and development of allotment gardens should be sought in socio-economic changes associated with the industrialisation period. What is alarming today, is the opinion that those plots of land supposedly restrict the spatial development of urbanised areas. In addition to their numerous socio-economic functions, allotments are an important element in the implementation of the idea of sustainable development, and as such they should play a special role in the spatial policy of urban areas. The main goal of this paper is to present the development of family allotment gardens in Poland and their current number, structure and location in the Poznań agglomeration. An attempt was made to formulate recommendations for a spatial policy of the agglomeration and towards this goal data obtained from Polish Association of Allotment Holders and Central Statistical Office was analysed. In addition, field studies and survey research were conducted.
\end{abstract}

Key words: allotment gardens, green infrastructure, utility gardens, community gardens, urban horticulture.

\section{Introduction}

In Poland, family allotment gardens (FAGs), are important components of urban greenery performing many significant functions for a city and its inhabitants. In accordance with $\S 5$ of FAG Regulation, FAGs as public utility facilities play a beneficial role in urban planning and in the ecosystems of towns and settlements, improving the living conditions of a local community and owners' families. Their special importance lies in the fact that they help to shape the environment, protect and preserve 
elements of nature, conduct and propagate ecological activity, and carry out wide-ranging work for a local community (Uchwała Krajowej Rady... 2014).

Polish allotment gardens have a rich tradition and a history more than a hundred years long. The reasons for the appearance and development of allotment gardening should be sought in socio-economic changes associated with the period of industrialisation, when such green spaces were called "workers' allotment gardens". As in other European cities, their function was mainly to supply food. However, today one can observe a gradual replacement of the productive use of allotments by the recreational ones. In the opinion of Szkup (2013), the proof of a change in the old functions is the proportion of plots with the predominance of minimum-investment areas, usually lawns. Besides, garden sheds - places for a short rest - have often developed into fully equipped houses, which can confirm the recreational nature of a plot. Because of their central location in a city or along heavy-traffic roads (Mierzejewska 2001), their closed (non-public) nature (Szczęsny \& Kimic 2012) and highly diversified architecture (Romanowski 2012), a further functioning of allotment gardens in the present form is becoming increasingly controversial in many cities. With the growing density of buildings, a deficit of municipal public gardens and parks, and changing social needs and economic conditions, allotment gardens seem to be more significant as a space for use by the public than ever before.

The main goal of this paper is to present the development of family allotment gardens in Poland and their current number, structure and location in the Poznań agglomeration. Another aim is to identify functions they perform today and the possibilities of their transformation. An attempt was also made to formulate guidelines for their further functioning in urban space. In the research, data from the Central Statistical Office (GUS 2015) and the Polish Association of Allotment Holders - PAAH (PZD 2015) were used, as well as cartographic materials, planning documents and legal acts. The primary material and data come from a survey research and fieldwork (an inventory), which was conducted between June and September 2015. In order to obtain detailed information about the present use of FAGs and relevant opinions on their future functions in urban space, a survey research was carried out in 30 allotment gardens and 10 parks in Poznań. The gardens belonged to the PAAH, and they as well as parks covered by the research were randomly selected. In total, the study covered 294 people: 158 plot holders and 136 people who had no plots. Paper questionnaires were distributed in gardens and parks among those who agreed to take part in the study. The survey included open and closed-end questions. The respondents could choose several answers, which concerned the use, operation and management of garden allotments and plots.

In the present text, the following terms and abbreviations are used: family allotment gardens (FAGs), understood as allotment gardens belonging to the Polish Association of Allotment Holders (PAAH), an allotment garden as a form of a public garden and green area, an allotment gardens colony - a complex of allotment gardens, and plots - individual parts of an allotment managed and cultivated by the tenant (an allotment garden holder), usually with a shed on it.

\section{The history and present day of allotments}

The roots of allotment gardening go back to the 19th century, a period of the rapid development of towns, their industrialisation, and the inflow of thousands of people from rural areas. The first allotments appeared in Great Britain and Germany. They were mainly philanthropic in character, a form of social help for the poorest, usually workers', families. In a later period, during the First 
World War, there appeared gardens with predominantly economic functions - 'victory gardens', set up to improve the population's living conditions. Then their chief aim was to obtain the most abundant crops possible. Because of war damage, also the construction of garden sheds was allowed as a temporary solution. In the successive years, the primary function of allotments was to ensure a healthy place for family recreation, with great emphasis put also on their role in the formation of social attitudes and cooperation skills (Pawlikowska-Piechotka 2010). Family allotments are still present in many countries of Europe, e.g. Austria, Belgium, Denmark, Finland, France, Germany, Great Britain, Luxembourg, the Netherlands, Norway, Sweden, and Switzerland. Since 1926, European allotment holders have been associated in the International Office of Allotments and Family Gardens (Office International... 2015).

It is believed that the first allotment garden in Poland appeared in 1897 in Grudziądz, and it was called 'The Sunny Bath'. In 1918, after Poland had regained independence, there were 19 allotment gardens divided into 2,064 plots with a total area of 70.16 ha. In 1937, just before the outbreak of the Second World War, the number of allotment gardens grew to 421, with 48,209 plots totalling 2,704.68 ha in area. A decided majority of garden allotments colonies were located in Wielkopolska (104) and Silesia (103) (Lubawy 1937). In Poland, as in other countries, the reasons for creating allotments were their advantages and social significance in terms of health as well as moral, educational, material and aesthetic aspects (Wilczyński 1927). Since the very start of allotments (then often called colonies), attempts have been made to work out some detailed guidelines concerning the location, size and design of entire gardens and individual allotments. In the opinion of Wilczyński (1927), setting up gardens was a public duty in the same way as schools or hospitals. The most suitable gardens were said to be those with 300 to 400 plots of $300-500 \mathrm{~m}^{2}$. Special attention was paid to their location close to major clusters of the working population, but far from factories. When looking for the location of a garden, the priority was a permeable soil. It was the task of the local authorities to connect a colony to a road and a water main, and to provide an instructor - an experienced gardener. It is worth mentioning that much care was taken in Poznań to equip such gardens with generally accessible infrastructure for the youngest ones, i.e. not only for the children of allotment holders. Popular facilities included a playground, a roofed hall for games and exercises under the supervision of older persons or a qualified care taker (Fig. 1), a swimming pool and a beach for water- and sun-bathing. A special place in the implementation of the idea of allotment gardens was given to the program of providing extra food to children. 

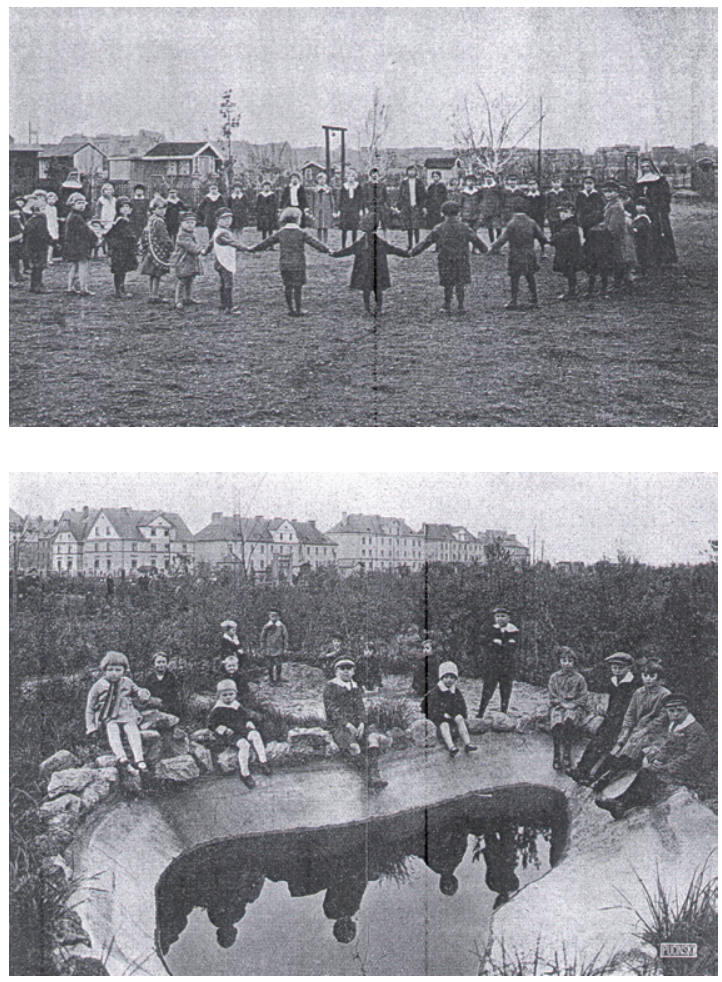

Figure 1. Children on the playground and a water pool in allotment gardens colony in Poznań Source: Wilczyński (1927).

After the Second World War, in the years of an intensive development of allotment gardening, several guidelines were laid down concerning the entire gardens, individual plots, and garden sheds.
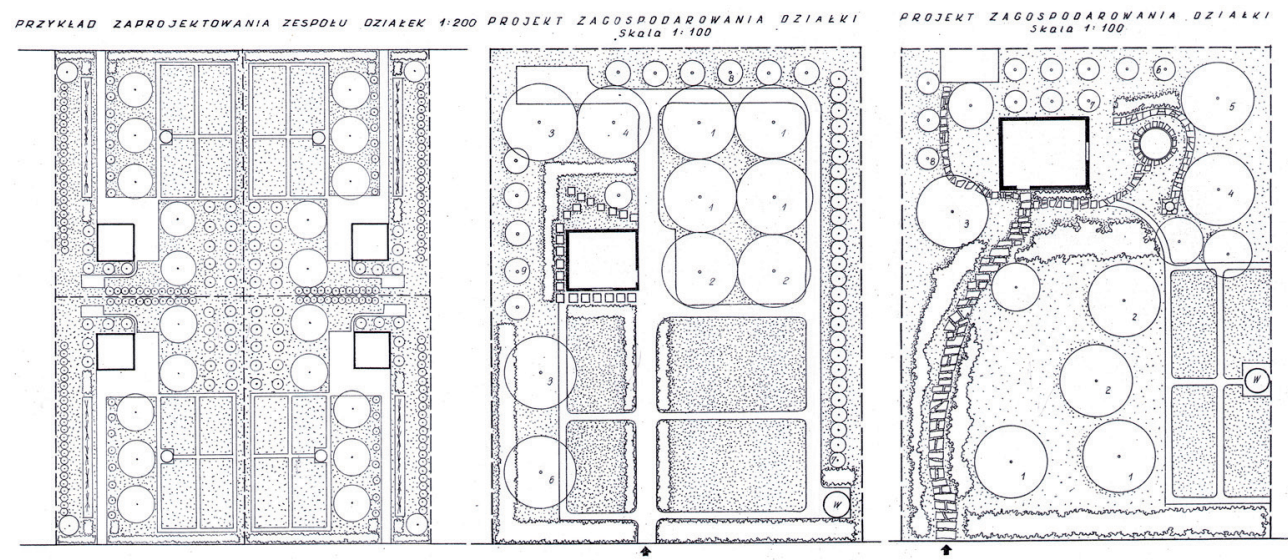

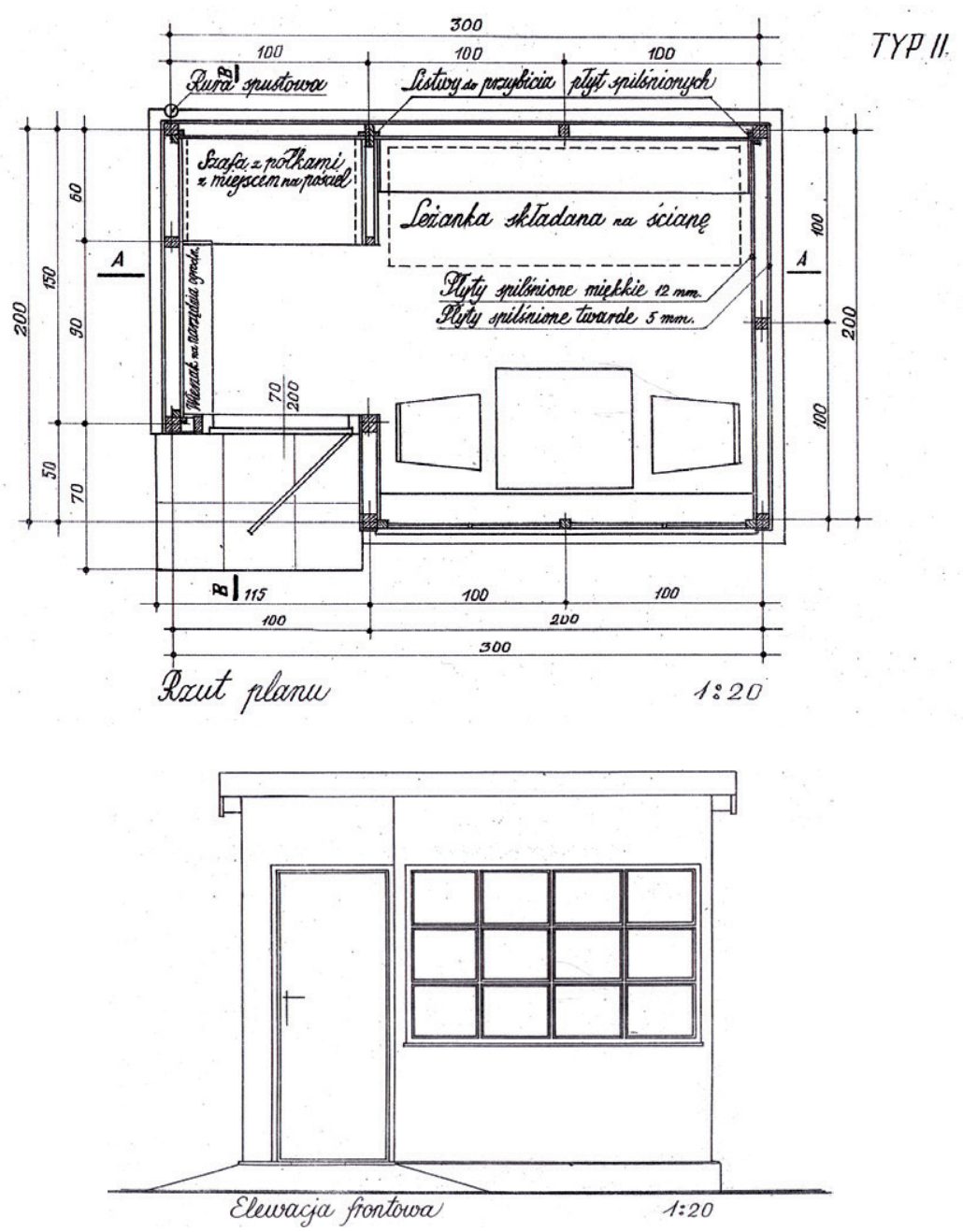

Figure 2. Old designs for gardens, plots and garden houses - examples of a good practice Source: Krajowa Rada... (1966).

Particular attention should be paid to the small size of modestly equipped sheds and a very practical layout of the plot - examples of a vegetable plot, an orchard and a part with decorative plants (Fig. 2). This was supposed to prevent the construction of garden shelters against basic aesthetic principles. And the proper planning of an allotment was intended to ensure its rational productive and recreational use, taking into consideration the size of the owner's family, the kind of soil and micro-climate determining the choice of species and varieties of plants to be grown, the area, insolation of the allotment, etc. These guidelines allowed for determining the size of the crops (Krajowa Rada... 1966).

The Family Allotment Gardens Act (Uchwała o rodzinnych... 2014) currently in force defines allotment gardens as permanent elements of the infrastructure of communes that should be taken into consideration in the process of their development for the good of the present and future genera- 
tions. Moreover, it is considered necessary to guarantee their further existence and development. However, there are no detailed guidelines for the implementation of those recommendations in the spatial policies of territorial units. The Act (2014) contains some provisions concerning technical requirements: the distance of a shed from each boundary cannot be less than $3 \mathrm{~m}$; the permitted building area for a FAG located within city limits is $25 \mathrm{~m}^{2}$, outside them it is $35 \mathrm{~m}^{2}$; the height of the arbor with a pitched roof cannot exceed $5 \mathrm{~m}$, and with another type of roof, $4 \mathrm{~m}$; sheds can have a terrace of max. $12 \mathrm{~m}^{2}$.

The current Study of Conditions and Directions of Spatial Development of Poznań (Studium... 2014) assumes maintaining the existing FAGs and suggests taking measures intended to: locate new allotments in peripheral areas as elements complementing the city's system of greenery; introduce green belts isolating allotments from nearby heavy-traffic transport routes, including motorways, and from industrial facilities; give preference to openwork fencing in order to allow migration of small animals (with the exception of allotments neighbouring on roads of classes $G$ and GP); forbid the transformation of existing garden houses into buildings for everyday and year-round living or recreation; and limit the height of accompanying facilities (common rooms, technical buildings) to one above-ground storey, and locate car parks and waste collection points within the allotment area.

Comparative studies of the spatial policies of Warsaw and Poznan show that little attention is paid to allotment gardens. They are often treated as a reserve for the development of other green areas or as investment areas. Too little attention is paid to their social and environmental functions (Gierdych \& Poniży 2013). Currently, there is no leading spatial planning strategy for allotment gardens and there is no European national thinking or standards. Allotment gardens are temporarily used pieces of land - until there appear other ideas of spatial planning (Bell et al. 2016).

\section{Results and discussion}

\section{Number, structure and location of allotment gardens}

There are about 4,926 allotment garden colonies in Poland consisting of 963,351 plots with a total area of 43,237 ha (GUS 2015). A majority are located in cities, usually ones with an industrial past. An analysis of statistical data shows that between 2003 and 2013 the number of FAGs dropped in all voivodeships (Fig. 3) from 5,199 to 4,926 , or by $5.2 \%$. The steepest decline was recorded in the voivodeships of Łódź (42), Wielkopolska (30), and Lower Silesia (28). Their greatest number can be found in Silesia (688), Lower Silesia (536) and Wielkopolska (534), and it is in those voivodeships that FAGs are also the biggest (the mean size of an allotment being $8.7 \mathrm{ha}$ ). The fewest FAGs are registered in Świętokrzyskie (79), Podlaskie (104) and Opolskie (111) voivodeships. 


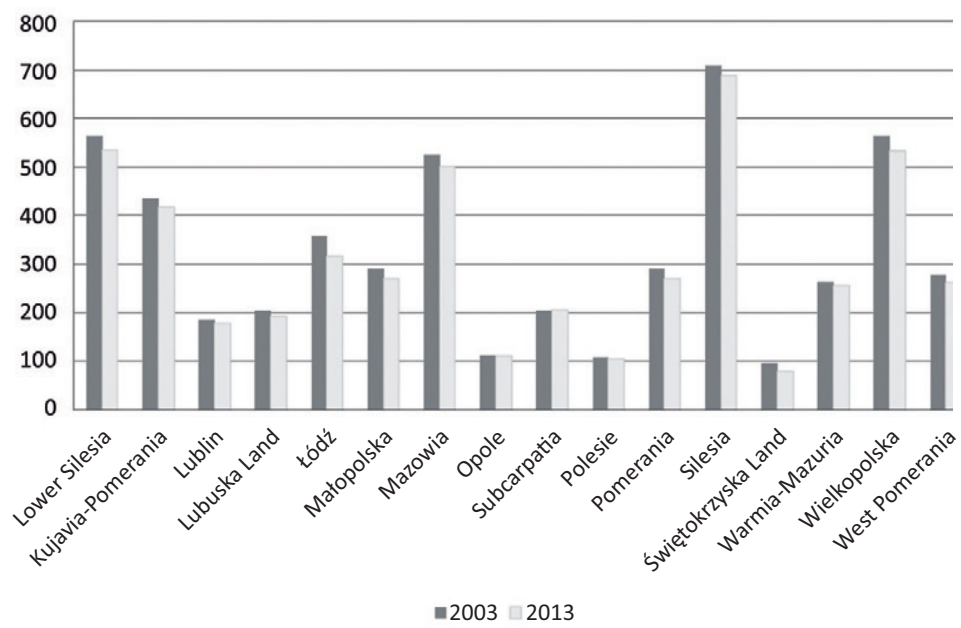

Figure 3. Number of family allotment gardens in Poland by voivodeship in 2003 and 2013 Source: own compilation, based on the data of GUS 2015.

The data provided by the PAAH show that in 2014 there were 148 family allotment gardens in the Poznan agglomeration totalling 1,511 ha, which accounted for $0.8 \%$ of its area. $61 \%$ of them were located in the city of Poznan itself. The mean area of an allotment in individual communes of the agglomeration ranged from 2.8 (Rokietnica) to 33.5 ha (Dopiewo), the general mean being $10.2 \mathrm{ha}$. The total number of plots was 31,474, their mean area ranging from $294 \mathrm{~m}^{2}$ (Luboń) to $476 \mathrm{~m}^{2}$ (Kostrzyn), the general mean being $362 \mathrm{~m}^{2}$ (Tab. 1). Over two-thirds of all FAGs were located in zones 1 and 2, i.e. 5 and $10 \mathrm{~km}$ from the city centre, respectively (Fig. 4).

Table 1. Family allotment gardens in the Poznań agglomeration in 2015

\begin{tabular}{|l|c|c|c|c|c|c|c|}
\hline \multicolumn{1}{|c|}{ Community } & $\begin{array}{c}\text { Number } \\
\text { of FAGs }\end{array}$ & $\begin{array}{c}\text { Total area } \\
\text { of FAGs } \\
\text { [ha] }\end{array}$ & $\begin{array}{c}\text { Average } \\
\text { FAGs area } \\
\text { [ha] }\end{array}$ & $\begin{array}{c}\text { Number } \\
\text { of plots }\end{array}$ & $\begin{array}{c}\text { Total } \\
\text { area of } \\
\text { plots [ha] }\end{array}$ & $\begin{array}{c}\text { Share of } \\
\text { plots area } \\
\text { in FAGs } \\
\text { area [\%] }\end{array}$ & $\begin{array}{c}\text { Average } \\
\text { of plot area } \\
\text { [m²] }\end{array}$ \\
\hline Buk & 3 & 15.2 & 5.1 & 292 & 10.5 & 68.9 & 360 \\
\hline Czerwonak & 5 & 25.0 & 5.0 & 608 & 19.9 & 79.7 & 328 \\
\hline Dopiewo & 2 & 67.0 & 33.5 & 1,054 & 43.3 & 64.5 & 410 \\
\hline Komorniki & 2 & 12.9 & 6.5 & 169 & 6.9 & 53.4 & 409 \\
\hline Kostrzyn & 2 & 9.1 & 4.6 & 165 & 7.8 & 85.8 & 476 \\
\hline Kórnik & 6 & 93.4 & 15.6 & 1,710 & 69.2 & 74.1 & 405 \\
\hline Luboń & 4 & 21.1 & 5.3 & 539 & 15.9 & 75.3 & 294 \\
\hline Mosina & 3 & 17.9 & 6.0 & 347 & 11.6 & 64.5 & 334 \\
\hline Murowana Goślina & 1 & 7.1 & 7.1 & 139 & 5.8 & 81.5 & 414 \\
\hline Pobiedziska & 8 & 140.8 & 17.6 & 2,403 & 102.2 & 72.5 & 425 \\
\hline Rokietnica & 2 & 5.7 & 2.8 & 87 & 4.1 & 71.5 & 468 \\
\hline Stęszew & 2 & 16.3 & 8.1 & 298 & 10.7 & 65.6 & 359 \\
\hline
\end{tabular}




\begin{tabular}{|l|c|c|r|r|r|r|c|}
\hline \multicolumn{1}{|c|}{ Community } & $\begin{array}{c}\text { Number } \\
\text { of FAGs }\end{array}$ & $\begin{array}{c}\text { Total area } \\
\text { of FAGs } \\
\text { [ha] }\end{array}$ & $\begin{array}{c}\text { Average } \\
\text { FAGs area } \\
\text { [ha] }\end{array}$ & $\begin{array}{c}\text { Number } \\
\text { of plots }\end{array}$ & $\begin{array}{c}\text { Total } \\
\text { area of } \\
\text { plots [ha] }\end{array}$ & $\begin{array}{c}\text { Share of } \\
\text { plots area } \\
\text { in FAGs } \\
\text { area [\%] }\end{array}$ & $\begin{array}{c}\text { Average } \\
\text { of plot area } \\
\text { [m²] }\end{array}$ \\
\hline Suchy Las & 7 & 126.4 & 18.1 & 2,443 & 101.6 & 80.4 & 416 \\
\hline Swarzędz & 5 & 48.9 & 9.8 & 932 & 35.5 & 72.5 & 381 \\
\hline Tarnowo Podgórne & 6 & 84.2 & 14.0 & 1,521 & 61.0 & 72.5 & 401 \\
\hline Poznań & 90 & 819.7 & 9.1 & 18,767 & 633.5 & 77.3 & 338 \\
\hline TOTAL & 148 & $\mathbf{1 , 5 1 1 . 1}$ & 10.2 & $\mathbf{3 1 , 4 7 4}$ & $\mathbf{1 , 1 3 9 . 5}$ & $\mathbf{7 5 . 4}$ & $\mathbf{3 6 2}$ \\
\hline
\end{tabular}

Source: own compilation, based on the PZD 2015.

The most numerous allotments are those established immediately after the Second World War, in the period of an intensive reconstruction of the country, and in 1980s, when allotments started to be located in the city peripheries - the neighbouring communes (Fig. 5). In the Poznań agglomeration, the most numerous are gardens with allotments of 2 to 10 ha in area (58.8\%), divided into up to 200 plots (67.6\%), and with an average plot area of 301 to $500 \mathrm{~m}^{2}(81.1 \%$, Tab. 2, 3, 4).

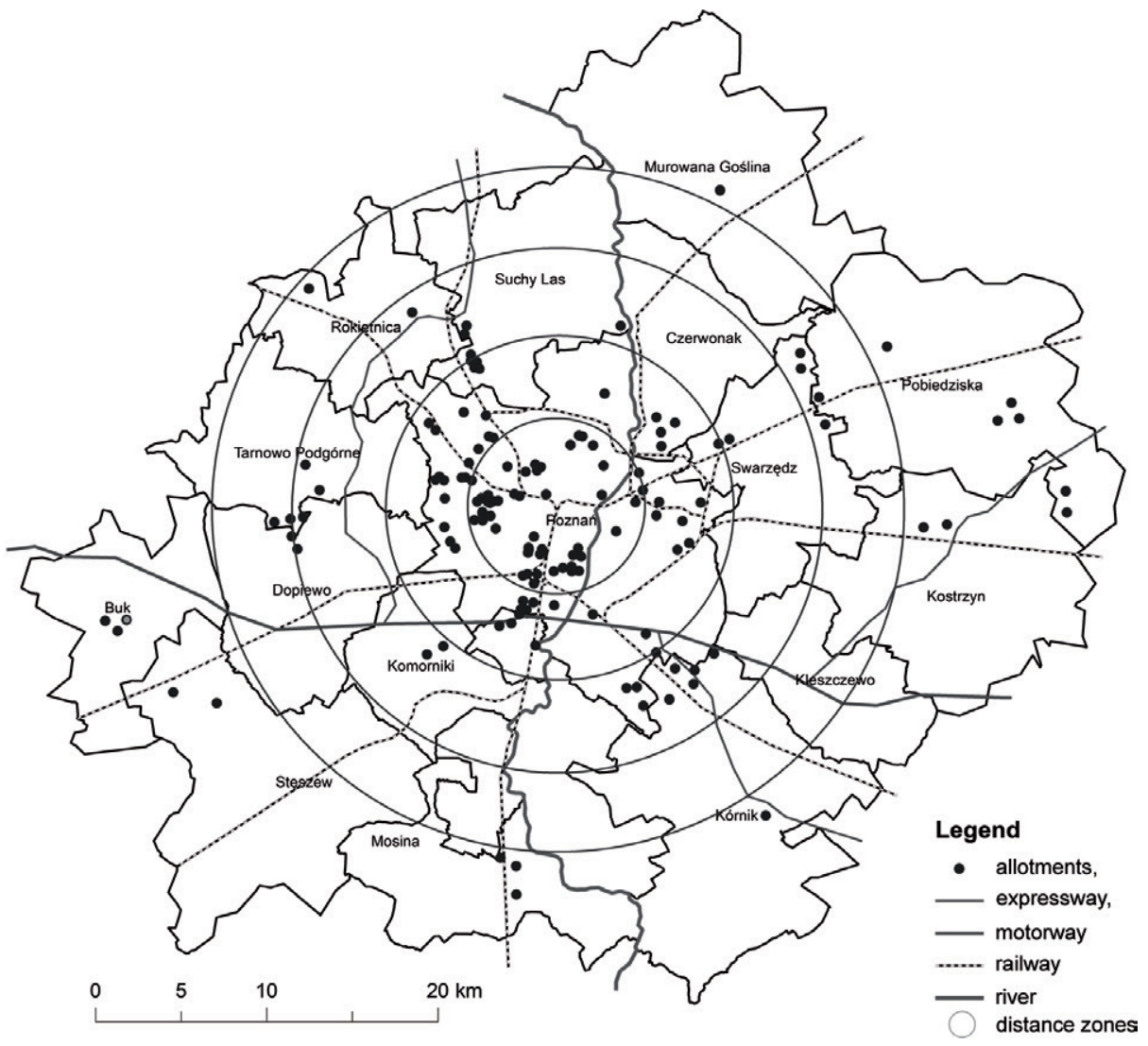

Figure 4. Location of family allotment gardens in the Poznań agglomeration relative to the city centre Source: own compilation, based on the PZD 2015. 


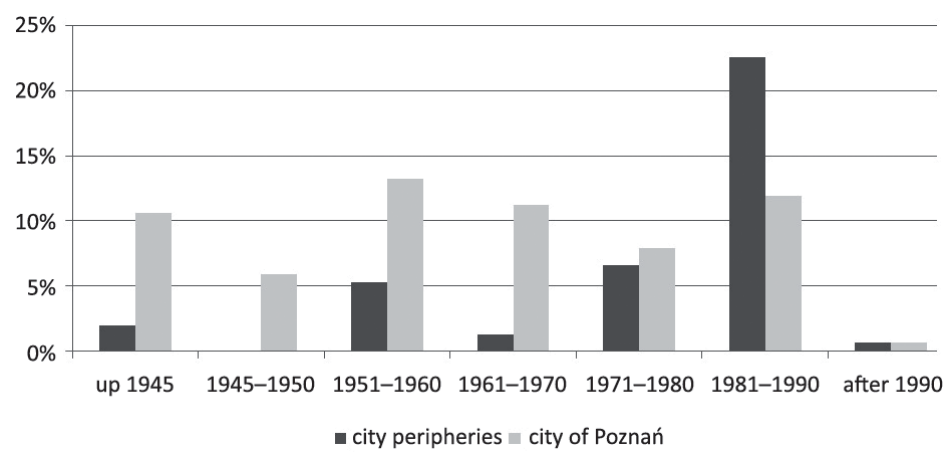

Figure 5. Family allotment gardens in the Poznań agglomeration - the time of establishment Source: own compilation, based on the PZD 2015

Table 2. Differences among family allotment gardens in the Poznań agglomeration - the area of a garden colony

\begin{tabular}{|c|c|c|}
\hline Area of FAGs [ha] & Number of FAGs & Share in total number of FAGs [\%] \\
\hline$<2$ & 9 & 6.1 \\
\hline $2-5$ & 45 & 30.4 \\
\hline $5-10$ & 42 & 28.4 \\
\hline $10-20$ & 29 & 19.6 \\
\hline$>20$ & 23 & 15.5 \\
\hline
\end{tabular}

Source: own compilation, based on the PZD 2015.

Table 3. Differences among family allotment gardens in the Poznań agglomeration - the number of plots

\begin{tabular}{|c|c|c|}
\hline Number of plots & Number of FAGs & Share in total number of FAGs [\%] \\
\hline$<100$ & 47 & 31.8 \\
\hline $100-200$ & 53 & 35.8 \\
\hline $201-300$ & 19 & 12.8 \\
\hline $301-400$ & 8 & 5.4 \\
\hline $401-500$ & 6 & 4.1 \\
\hline$>500$ & 15 & 10.1 \\
\hline
\end{tabular}

Source: own compilation, based on the PZD 2015.

Table 4. Differences among family allotment gardens in the Poznań agglomeration - the average plot area

\begin{tabular}{|c|c|c|}
\hline Average plot area $\left[\mathrm{m}^{2}\right]$ & Number of FAGs & Share in total number of FAGs [\%] \\
\hline$<250$ & 6 & 4.1 \\
\hline$>500$ & 6 & 4.1 \\
\hline $250-300$ & 16 & 10.8 \\
\hline $301-400$ & 84 & 56.8 \\
\hline $401-500$ & 36 & 24.3 \\
\hline
\end{tabular}

Source: own compilation, based on the PZD 2015. 
Table 5. Family allotment gardens within the administrative limits of Poznan

\begin{tabular}{|l|c|c|c|c|c|c|c|}
\hline \multicolumn{1}{|c|}{ District } & $\begin{array}{c}\text { Number } \\
\text { of FAGs }\end{array}$ & $\begin{array}{c}\text { Total } \\
\text { FAGs } \\
\text { area [ha] }\end{array}$ & $\begin{array}{c}\text { Average } \\
\text { FAGs area } \\
\text { [ha] }\end{array}$ & $\begin{array}{c}\text { Number } \\
\text { of plots }\end{array}$ & $\begin{array}{c}\text { Area of } \\
\text { plots [ha] }\end{array}$ & $\begin{array}{c}\text { Share of plots } \\
\text { area in FAGs } \\
\text { area [\%] }\end{array}$ & $\begin{array}{c}\text { Average } \\
\text { plot area } \\
\text { [m²] }\end{array}$ \\
\hline Stare Miasto & 6 & 43.8 & 7.3 & 1,041 & 34.1 & 78.0 & 327.9 \\
\hline Nowe Miasto & 17 & 195.2 & 11.5 & 4,231 & 158.7 & 81.3 & 375.1 \\
\hline Wilda & 16 & 123.0 & 7.7 & 2,755 & 90.1 & 73.2 & 327.0 \\
\hline Grunwald & 17 & 194.9 & 11.5 & 4,568 & 145.6 & 74.7 & 318.8 \\
\hline Jeżyce & 34 & 262.9 & 7.7 & 6,172 & 204.9 & 77.9 & 332.0 \\
\hline CITY & 90 & 819.8 & 9.1 & 18,767 & 633.5 & 77.3 & 337.5 \\
\hline POVIAT & 58 & 691.3 & 11.9 & 12,707 & 506.0 & 73.2 & 398.2 \\
\hline TOTAL & 148 & $1,511.1$ & 10.2 & 31,474 & $1,139.5$ & 75.4 & 362 \\
\hline
\end{tabular}

Source: own compilation, based on the PZD 2015.

The city district with the largest number of FAGs is Jeżyce (34), where they are part of one of the major wedges of urban greenery. Their number is smallest in the Stare Miasto district (6), where they are all similar in area (about 7 ha). The largest FAGs (of about 11 ha) can be found in Nowe Miasto and Grunwald. The mean area of a plot in the city $\left(337.5 \mathrm{~m}^{2}\right)$ is smaller than its mean area in the agglomeration (398.2 $\left.\mathrm{m}^{2}\right)$ (Tab. 5).

\section{Allotment gardens in survey researches and fieldwork}

It is estimated that close to a million families, or some $3,600,000$ people, spend their leisure time on allotments ( $10 \%$ of the population). Polish allotment holders are primarily old-age pensioners (42.07\%), disability pensioners (11.23\%), and working persons $(42.49 \%)$, while unemployed people represent the smallest share (4.21\%) of allotment holder (Kim sq polscy działkowcy? 2011).

The survey carried out among plot holders in 30 allotment gardens in the Poznań agglomeration revealed that the productive function of such facilities tended to give way to a recreational one. As many as $72 \%$ of respondents stated that over the last 20 years the character of their plots had changed in this respect. Half of them (52\%) described the character of their plots as recreational-productive, $39 \%$ as exclusively recreational, and $9 \%$ as exclusively productive. This finding was corroborated by an inventory of plots in J. Mazurek FAGs in Poznań (Fig. 6). For the purpose of the field study, 3 types of plots were determined, with the following characteristics:

- productive - a significant predominance of a cultivated area and the presence of a greenhouse or a plastic tunnel;

- recreational-productive - the predominance of a recreational area, a significant share of the lawn and individual elements of recreational infrastructure;

- recreational - no crops, only a lawn, ornamental and evergreen vegetation, and rich recreational infrastructure.

$49 \%$ of plots were inventorised as recreational-productive, $22 \%$ as recreational, and $17.5 \%$ as productive. The remaining $11.2 \%$ were difficult to define because of their poor condition (neglected, disordered, deserted). According to Stachura (2013), plots in Poznań are cultivated for food (30\%) and ornamental plants (30\%). In turn, the PAAH data (Kim sq polscy działkowcy? 2011) show that in the Poznań district a mere $15 \%$ of plots are geared to plant cultivation, $27 \%$ are recreational, and $58 \%$ are recreational-productive. 


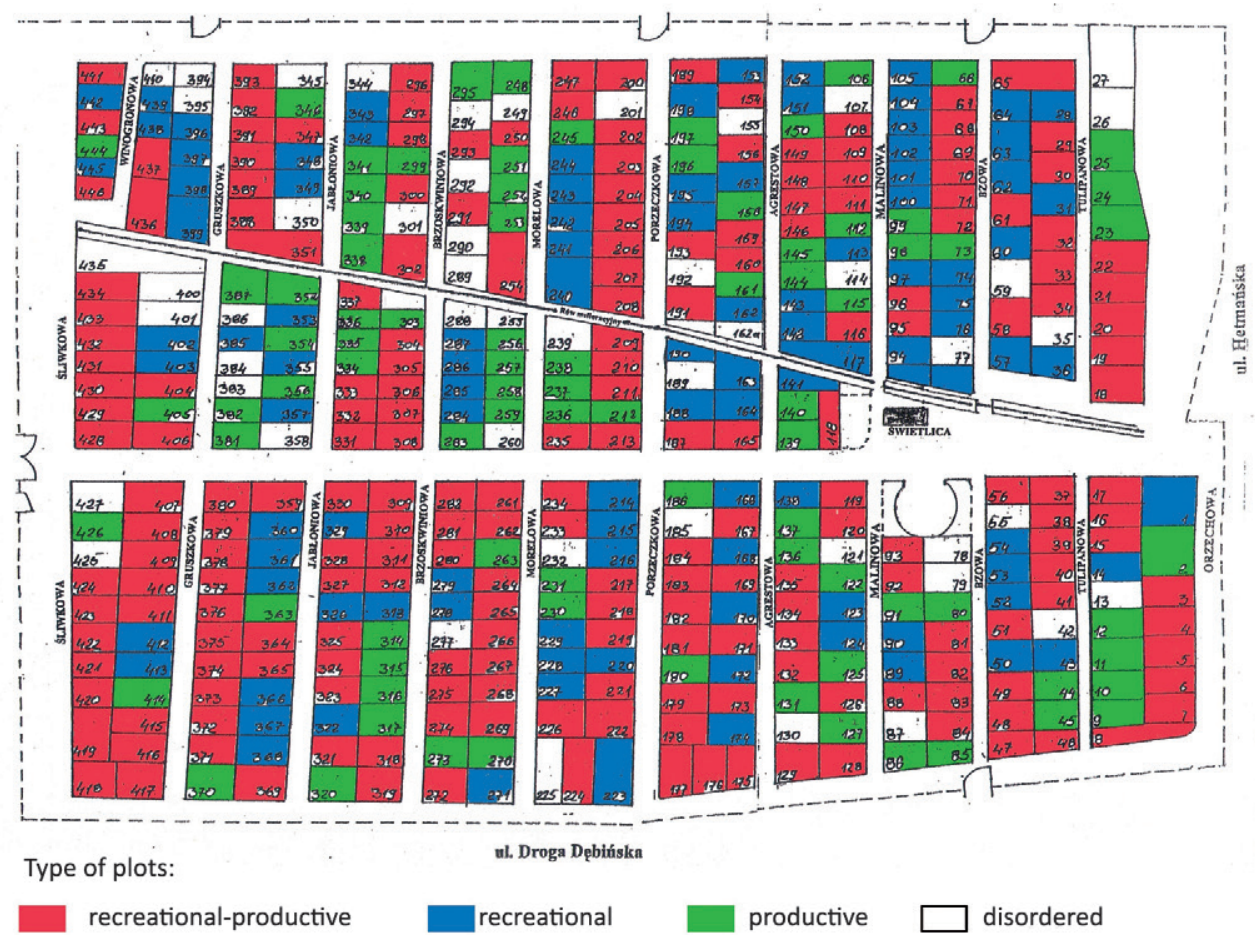

Figure 6. Structure of the use of plots in the J. Mazurek family allotment garden in Poznan Source: own compilation, based on the fieldwork.

Table 6. Comparison of the types of plots according to different sources (in percent)

\begin{tabular}{|l|c|c|c|c|}
\hline \multicolumn{1}{|c|}{ Type of plots } & $\begin{array}{c}\text { According to 'Kim są } \\
\text { polscy działkowcy?' } \\
\text { (2011) in \% }\end{array}$ & $\begin{array}{c}\text { According to } \\
\text { Stachura (2013) } \\
\text { in \% }\end{array}$ & $\begin{array}{c}\text { According } \\
\text { to fieldwork } \\
\text { (\%) }\end{array}$ & $\begin{array}{c}\text { According to } \\
\text { survey research } \\
\text { (\%) }\end{array}$ \\
\hline Recreational-productive & 58 & 40 & 49 & 52 \\
\hline Recreational/ornamental & 27 & 30 & 22 & 39 \\
\hline Productive & 15 & 30 & 17 & 9 \\
\hline
\end{tabular}

Source: own compilation. 

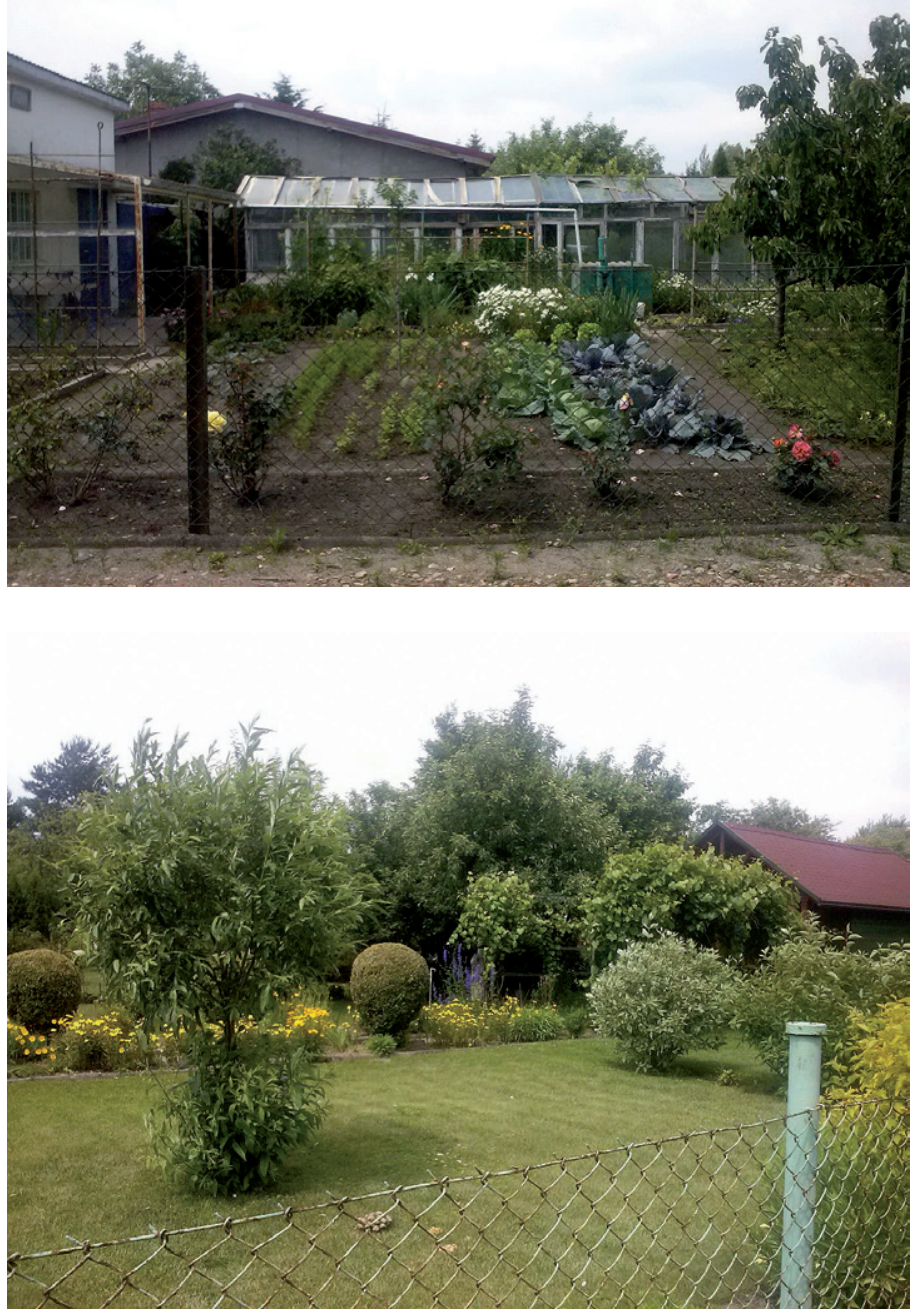

Figure 7. Present use of plots - productive and recreational types of plots (photo M. Szczepańska)

The results of the survey (Tab. 7) show differences in the opinions of residents and plot holders as to the future of allotment gardens. According to plot holders (82\%), allotment gardens should exist in their present form - most plot holders do not want any change, fearing the liquidation of allotment gardens. They are also against giving all residents access to their gardens. But they would approve cooperation with schools and care facilities (37\%), as well as the organisation of various festivities (22\%) and gardening courses (18\%). A frequently expressed opinion concerning potential changes was that it would be good to making it possible to sell vegetables, fruits, herbs and flowers cultivated in allotment gardens (33\%). Both groups of respondents recognise the potential of allotment gardens as green areas ( $32 \%$ and $45 \%)$ as well as their ecological functions ( $26 \%$ and $58 \%$ ). 
However, according to residents (23\%), allotment gardens have a negative impact on the landscape of the city; a similar view is shared by only $7 \%$ of plot holders.

Table 7. Opinion about the future of allotment gardens

\begin{tabular}{|l|c|c|}
\hline \multicolumn{1}{|c|}{ Opinion about the future of allotment gardens } & $\begin{array}{c}\text { Residents } \\
\text { (\%) }\end{array}$ & $\begin{array}{c}\text { Plot holders } \\
\text { (\%) }\end{array}$ \\
\hline Number of allotment gardens is sufficient & 14 & 20 \\
\hline Allotment gardens should exist in their present form & 27 & 82 \\
\hline Allotment gardens should be accessible to all residents & 41 & 17 \\
\hline Allotment gardens are important components of green areas & 32 & 45 \\
\hline Allotment gardens help to improve ecological conditions of city environment & 26 & 58 \\
\hline Allotment gardens limit development of city & 11 & 9 \\
\hline Allotment gardens have negative impact on city landscape and aesthetics & 23 & 7 \\
\hline
\end{tabular}

Source: own compilation, based on the survey research.

As follows from a study by Mierzejewska (2001), more than half of respondents opted for moving the gardens to the outskirts (77\%), for transforming them into recreational grounds (76\%) or for building them up (32\%), while $27 \%$ were for keeping allotments in the city centre.

\section{Urban gardening as a possible conception to be used in the process of allotment gardens transformation}

Today, a special role in shaping urban space is played by the conception of 'green infrastructure' (Madureira \& Andersen 2014), according to which urban green areas, including also allotment gardens, are places favourable to biological diversity, making it possible for ecosystems to endure and operate by a combination of urban, suburban and rural features. It is worth noting that FAGs are an important part of the green infrastructure of the agglomeration ( $23 \%$ of public green spaces), in some communes (Dopiewo, Kórnik, Pobiedziska and Suchy Las) they constitute up to $80 \%$ of green areas (Szczepańska et al. 2016).

Besides, given the historical, food-providing functions of allotments and the results of the reported survey research indicating possible changes in allotments' functioning, a spatial policy taking into consideration what urban horticulture has to offer should be an important issue for modern Polish cities. Urban horticulture enriches spatial forms and structures of a city as well as its image. It also makes it possible for urban community to get locally grown food. Since 1970, urban farming has occupied a prominent place in the planning of large West European cities. Several measures have been taken to protect this kind of farming, and even to restore it. Urban farming is regularly monitored and supported financially by the authorities of such cities as Paris, Vienna and Stuttgart, as well as in the Ruhr Basin (Mougeot 2005 and 2006; Giecewicz 2005; Steinbuch 2012; Krzyk et al. 2013). Agriculture operates in the Poznań agglomeration under a very strong pressure of intensive urbanisation processes. Although in the recent years much emphasis is put on the multifunctionality of urban agriculture, the farmland area keeps shrinking and agricultural production keeps being pushed out into the peripheries of the agglomeration. The analysis conducted shows that measures should be taken to counteract its marginalisation. Environmental and economic considerations speak for rational management of agricultural areas in the Poznań agglomeration (Szczepańska et al. 2015). 
The substantial social role of allotment gardens in Poland and people's expectations as to their easier availability brings to mind the so-called community gardens that have lately been gaining popularity in West European countries. Gardens of this type are set up as bottom-up initiatives and, supported by local authorities, they contribute to the integration of local community and function as places of social meetings or even cultural events (festivities, concerts, film projections). They are also places of ecological education and promotion of a healthy lifestyle. The cultivation of plants in them is safe, both for people and for the environment, and their produce is used by community members (Latkowska 2012). In Poland, traditional allotment gardens still predominate, while community gardens tend to be treated rather as temporary and occasional solutions.

It is also worth noting the therapeutic role of such gardens - the so-called "green therapy". A suitably designed and arranged garden can support and stimulate the healing process by releasing people from physical symptoms of a disease, reducing stress, and improving their general sense of comfort. Gardens with this type of layout can be found on the premises of health-care institutions (hospitals, rehabilitation centres, hospices) and social care facilities (nursing homes, old people's homes) as well as prisons. Horticultural therapy programmes (therapy through work in a garden) differ, depending on the garden facilities available, and primarily on the needs and capabilities of patients (Latkowska 2008). The idea of green therapy should be disseminated by giving the elderly, the sick and the disabled access to allotments. In Poznań, one of the allotment gardens offered a plot for use by the Association of Friends of the Blind and Visually Impaired. The problem of urban gardening can be also important as an instrument in process of social and spatial revitalization (Szczepańska \& Staszewska 2016).

Taking into account the positive impact of allotments on social life, Simms and Conisbee (2012) propose the establishment of a 'gardening leave'. Its introduction would make it necessary for various organisations and companies (public and private) to reduce the weekly working time, or to compress it to 4 days a week (a system introduced in the Netherlands). This is intended to improve the balance between work and leisure. The recovery of time for rest and leisure would have to be accompanied by local governments and enterprises providing space for urban agriculture. Firms involved in this kind of actions could use such land for their promotional activities, and public institutions could give preference to food from such sources in the competitions and tenders they organise.

\section{Conclusions}

The allotment gardens are a special element of city green infrastructure, improving the sanitary condition of the city. However, they do not appear explicitly in the definition of 'green areas' (Ustawa o ochronie przyrody... 2004), which can diminish their significance in the city's spatial policy. They are of great importance in the implementation of the idea of sustainable development, but their number keeps declining and the policy of city authorities does not give them sufficient protection. Today, FAGs tend to lose their productive function in favour of the decorative-recreational ones (e.g. picnics, festivities, competitions). Allotment users appreciate the ability to grow ecological and fresh produce for their own needs, and residents view FAGs as an important element of urban greenery. Therefore, the development of urban farming and pro-ecological initiatives of a social nature within agglomerations should be supported and allotment gardens should play a special role to play in this respect. The FAGs are chiefly places of recreation, increasingly assuming the form of summer-holiday lots (a lawn, a composition of evergreen plants, buildings, small garden structures, 
etc.). The diversified forms of building and layout as well as the absence of strict rules governing the development of those areas detract from their aesthetic value and deprive them of harmony and spatial order. The PAAH implements a social policy specifically intended to satisfy the needs of the elderly, the disabled and the children (e.g. occupational therapy workshops, classes, training courses) (http://www.poznan.pzd.pl). However, family allotment gardens are hardly accessible to city residents at large. It is advisable to strictly formulate the rules of their use, with special emphasis put on the aesthetic aspect and the neighbourhood context, and to establish cooperation in this area between city institutions (eg. schools, hospitals).

Based on literature examples, the collected information as well as the analyses and studies conducted, the following recommendations can be made:

- The liquidation of allotment gardens and their allocation to construction should be prevented, e.g. by finding new - social and economic - forms and functions. In planning documents, areas of liquidated allotment gardens should be secured, especially those in city centres (e.g. in order to transform them into parks or connectors of public spaces), strictly formulating the rules of their use, with special emphasis put on the aesthetic aspect and the neighbourhood context.

- A gradual opening of allotment gardens to the public is recommended (e.g. at weekends or in the summer season). Interesting initiatives could include the organisation of courses, workshops, meetings and occasional events, since this could boost the activation and integration of city residents and users, and thus prevent potential devastation.

- Allotment gardens, especially in suburban areas, should play a greater economic role (a requirement to grow useful plants), also including the sale of their produce (a stall, a marketplace).

Community gardens should be organised as a proposal for those who prefer to work in a group. It is advisable to cooperate with schools, nursing homes, hospitals, prisons, etc. in the field of education, rehabilitation and practical work, with special attention paid to the rules of green therapy.

\section{References}

Bell S., Fox-Kämper R., Keshavarz N., Benson M., Caputo S., Noori S., Voigt A., 2016. Urban Allotment Gardens in Europe. Routledge, Taylor and Francis Group, London and New York.

Giecewicz J., 2005. Obszary rolne jako czynnik przyrodniczej rewitalizacji miasta, Teka Komisji Architektury, Urbanistyki i Studiów Krajobrazowych PAN" vol. 1.

Giedrych R., Poniży L., 2013. Ogrody działkowe jako przedmiot polityki przestrzennej i ekologicznej miast na przykładzie Warszawy i Poznania [in:] Kosmala M. (ed.), Ogrody działkowe w miastach - bariera czy wartość?, Toruń: Polskie Zrzeszenie Inżynierów i Techników Sanitarnych, pp. 23-33.

GUS, 2015. Bank Danych Lokalnych, https://bdl.stat.gov.pl/BDL/dane/podgrup/temat [22 March 2016].

Kim sq polscy działkowcy? 2011, Warszawa: Krajowa Rada Polskiego Związku Działkowców.

Krajowa Rada Pracowniczych Ogrodów Działkowych przy Centralnej Radzie Związków Zawodowych, 1966. Projekty altan dla Pracowniczych Ogrodów Działkowych, Warszawa: Wydawnictwo Związkowe CRZZ.

Krzyk P., Tokarczuk T., Heczko-Hyłowa E., Ziobrowski Z., 2013, Obszary rolne jako element struktury przestrzennej miast - problemy planistyczne. Kraków: Instytut Rozwoju Miast.

Latkowska M., 2008. Hortiterapia - rehabilitacja i terapia przez pracę w ogrodzie. Zeszyty Problemowe Postępów Nauk Rolniczych, vol. 525, pp. 229-235. 
Latkowska M., 2012. „Community gardens”, czyli ogrody sqsiedzkie - nowe formy zieleni w przestrzeni miejskiej. Czasopismo Techniczne, Wydawnictwo Politechniki Krakowskiej, vol. 19, pp. 271-276. Lubawy W., 1937. Historia Ogrodów Działkowych w Polsce. Poznań: Związek Towarzystw Ogrodów Działkowych, Przydomowych, Małych Osiedli i Hodowli Drobnego Inwentarza Rzeczpospolitej Polskiej.

Madureira H., Andresen T., 2014. Planning for multifunctional urban green infrastructures: Promises and challenges. Urban Design International, vol. 19(1), pp. 38-49, http://doi.org/10. 1057/ udi.2013.11.

Mierzejewska L., 2001. Tereny zielone w strukturze przestrzennej miasta Poznania, Poznań: Wydawnictwo Poznańskiego Towarzystwa Przyjaciół Nauk, vol 29.

Mougeot L.J.A., 2000. Urban agriculture: definition, presence, potential and risks [in:] N. Bakker et al. (eds.), Growing cities, growing food: Urban agriculture on the policy agenda, A reader on urban agriculture, Feldafing: German Foundation for International Development.

Mougeot L.J.A., 2006. Growing better cities: Urban agriculture for sustainable development, Ottawa: International Development Research Centre.

Office International du Coin de Terre et des Jardins Familiaux, http://jardins-familiaux.org/office/ eoffice.html [22 March 2016].

Pawlikowska-Piechotka A., 2010. Tradycja ogrodów działkowych w Polsce, Gdynia: Novae Res - Wydawnictwo Innowacyjne.

PZD, 2015. Materiały wewnętrzne Polskiego Związku Działkowców Okręg w Poznaniu.

Romanowski H., 2012. Uwagi o architekturze ogrodów działkowych, Czasopismo Techniczne. Wydawnictwo Politechniki Krakowskiej. vol. 19, pp. 277-282.

Simms A., Conisbee M., 2012. National Gardening Leave. Why Britain would be better off if we all spent less time at the office, London: The New Economics Foundation. http://b.3cdn.net/ nefoundation/e9ccd872afac5574b2_azm6b4bpq.pdf [22 March 2016].

Stachura K., 2013. Environmental analysis of land use changes in green infrastructure of a city, with particular emphasis on allotment gardens: Poznań and Salzburg case study, http://www. urbanallotments.eu/fileadmin/uag/media/STSM/STSN_Report_Stachura.pdf [22 March 2016].

Steinbuch L., 2012. Nahrungsmittelproduktion in der Stadt. Konzepte für Stuttgart, Universität Stuttgart, Stuttgart.

Studium uwarunkowań i kierunków zagospodarowania przestrzennego miasta Poznania uchwalone uchwałq nr LXXII/1137/VI/2014 z 23 września 2014 r.

Szczepańska M., Staszewska S., 2016. Znacznie ogrodnictwa miejskiego w procesie rewitalizacji. Problemy Rozwoju Miast. Kwartalnik Naukowy Instytutu Rozwoju Miast , vol. III/2016, pp. 33-43.

Szczepańska M., Kołodziejczak A., Kacprzak E., 2015. Urban agriculture of the Poznań agglomeration. Studia Regionalia, pp. 41-42.

Szczepańska M., Krzyżaniak M., Świerk D., Urbański P., 2016. Rodzinne ogrody działkowe jako element zielonej infrastruktury na terenie aglomeracji poznańskiej, Studia Miejskie, vol. 22, pp. 129-142.

Szczęsny M., Kimic K., 2012. Możliwości adaptacji terenów ogrodów działkowych na obiekty ogólnodostępne na przykładzie Rodzinnego Ogrodu Działkowego przy kanale Gocławskim w Warszawie, Czasopismo Techniczne. Wydawnictwo Politechniki Krakowskiej, vol. 30, pp. 179-185.

Szkup R., 2013. Użytkowanie rodzinnych ogrodów działkowych przez społeczność wielkomiejskq. Wydawnictwo Uniwersytetu Łódzkiego.

Uchwała Krajowej Rady Polskiego Zwiqzzu Działkowców, 2014. 
Ustawa o ochronie przyrody z dnia 16 kwietnia 2004 r. (Dz.U. z 2004 r. Nr 92, poz. 880).

Ustawa o rodzinnych ogrodach działkowych z dnia 13 grudnia 2013 r. (Dz. U. z 2014 r., poz. 40). Wilczyński S., 1927. Ogródki działkowe jako zagadnienie społeczne, Poznań: Drukarnia św. Wojciech.

(c) 
